\title{
Influenza virus infection of well-differentiated human airway epithelial cells by infectious aerosols: insights into the
} earliest stages of infection [version 1; peer review: 2 approved with reservations]

\author{
Claire M. Smith (D1, Dani Do Hyang Lee1, Hemant Kulkarni², Priya Radhakrishnan1, \\ Robert Hirst ${ }^{2}$, Andrew Easton ${ }^{3}$, Chris O'Callaghan'1 \\ ${ }^{1}$ Department of Infection, Immunity and Inflammation, UCL GOS Institute of Child Health, London, UK \\ ${ }^{2}$ Department of Infection, Immunity and Inflammation, University of Leicester, Leicester, UK \\ ${ }^{3}$ School of Life Sciences, University of Warwick, Coventry, UK
}

V1 First published: 26 Mar 2019, 8:337

https://doi.org/10.12688/f1000research.18513.1

Latest published: 26 Mar 2019, 8:337

https://doi.org/10.12688/f1000research.18513.1

\section{Abstract}

Background: Influenza virus is a major human pathogen, yet surprisingly little data is available on the earliest stage of infection. We have developed a novel method to study natural transmission influenza infection by aerosol and to observe the effects of early infection on the ciliated airway epithelium using high-speed video microscopy.

Methods: Primary human ciliated epithelial cultures were infected with influenza $A(\mathrm{H} 1 \mathrm{~N} 1)$, delivered either by aerosol or by liquid immersion. Cells were stained for viral antigens and the level of inflammatory mediators, and the number of motile ciliated cells and ciliary beat frequency and pattern was measured.

Results: Infection by aerosol and liquid inoculums of influenza virus was shown to be trophic for ciliated cells. Infection by both methods also led to a significant decrease in the number of cells with motile cilia over the first 24 hours; however, the ciliary beat frequency and beat pattern of the remaining cilia was maintained over 24 hours. Conclusions: Influenza virus aerosols readily infect human ciliated nasal epithelial cells resulting in early loss of motile ciliated cells. Delivery of the virus by aerosol elicited an anti-inflammatory Th2 response, which was distinct from cells exposed to virus by liquid immersion delivery. This suggests our aerosol model may provide a more clinically relevant model for studying the early effects of influenza infection.

Keywords

influenza, cilia, airway epithelial cells

\section{Open Peer Review \\ Approval Status ? ? \\ 12

version $1 ?$ ? \\ 26 Mar 2019 \\ 1. Gemma L Saint ID, University of Liverpool, Liverpool, UK \\ 2. Kirsty R Short, The University of Queensland, St Lucia, Australia \\ Any reports and responses or comments on the article can be found at the end of the article.}




\section{This article is included in the UCL Child Health}

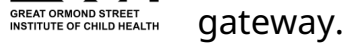

Corresponding author: Claire M. Smith (c.m.smith@ucl.ac.uk)

Author roles: Smith CM: Conceptualization, Data Curation, Formal Analysis, Investigation, Methodology, Project Administration, Resources, Supervision, Validation, Visualization, Writing - Original Draft Preparation, Writing - Review \& Editing; Do Hyang Lee D: Data Curation; Kulkarni H: Data Curation, Formal Analysis, Investigation; Radhakrishnan P: Data Curation; Hirst R: Supervision, Writing Review \& Editing; Easton A: Conceptualization, Formal Analysis, Writing - Review \& Editing; O'Callaghan C: Conceptualization, Funding Acquisition, Methodology, Resources, Supervision, Writing - Review \& Editing

Competing interests: No competing interests were disclosed.

Grant information: This work was supported by grants from Action Medical Research (SP4499 and SP4118). This research was supported by the NIHR Great Ormond Street Hospital Biomedical Research Centre. The views expressed are those of the authors and not necessarily those of the NHS, the NIHR or the Department of Health.

The funders had no role in study design, data collection and analysis, decision to publish, or preparation of the manuscript.

Copyright: ( 2019 Smith CM et al. This is an open access article distributed under the terms of the Creative Commons Attribution License, which permits unrestricted use, distribution, and reproduction in any medium, provided the original work is properly cited.

How to cite this article: Smith CM, Do Hyang Lee D, Kulkarni $\mathrm{H}$ et al. Influenza virus infection of well-differentiated human airway epithelial cells by infectious aerosols: insights into the earliest stages of infection [version 1; peer review: 2 approved with reservations] F1000Research 2019, 8:337 https://doi.org/10.12688/f1000research.18513.1

First published: 26 Mar 2019, 8:337 https://doi.org/10.12688/f1000research.18513.1 


\section{Introduction}

Influenza viruses cause annual epidemics that are associated with considerable morbidity and mortality ${ }^{1,2}$. The infectivity of influenza virus depends on the proteolytic cleavage of the haemagglutinin (HA) protein by host serine proteases ${ }^{3}$. The proteases are thought to be secreted by differentiated airway epithelial cells that are considered to be the main target for human influenza virus ${ }^{4-6}$. However, the cytopathogenesis of influenza virus, particularly in the earliest stages of infection, remains largely unknown.

We have previously used human ciliated epithelial cells in culture to evaluate the effects of bacteria and viruses ${ }^{7-11}$, observing ciliary function in real time using high-speed video photography. Work using ciliated epithelial models to investigate other viruses has provided significant insight into the pathophysiology of infection ${ }^{4-6,12-14}$. For example, respiratory syncytial virus (RSV) has been shown to be trophic for human ciliated cells ${ }^{10,14}$, inducing ciliary dyskinesia ${ }^{10}$, enhancing bacterial attachment ${ }^{10,15}$, and producing an inflammatory response early in the infectious process ${ }^{11}$.

The primary aim of this study was to evaluate the effect of influenza virus infection, either by aerosol or by liquid immersion, on ciliary function and inflammation of differentiated primary human nasal epithelial cells.

\section{Methods}

\section{Cell culture}

Human nasal epithelial cells were obtained from healthy control subjects $(n=9)$. Subjects had not experienced a symptomatic upper respiratory tract infection in the preceding 6 weeks. Primary ciliated epithelium was obtained by brushing the inferior nasal turbinate and cultured to air-liquid interface as previously described ${ }^{10}$.

Type-2 alveolar basal epithelial cells (A549) cells (American Type Culture Collection (ATCC), Manassas, VA) were grown in RPMI medium (Gibco) with $10 \%$ heat-inactivated foetal calf serum (Sigma), $100 \mathrm{U} / \mathrm{ml}$ penicillin, $10 \mu \mathrm{g} / \mathrm{ml}$ streptomycin (pen/strep) and fungizone. Madin-Darby canine kidney (MDCK) (ATCC, Manassas, VA) cells were grown to in Dulbecco's modified eagle medium (DMEM) with $10 \%$ foetal calf serum, and pen/strep as above.

\section{Virus strains and growth conditions}

Human influenza virus A/Puerto Rico/8/34 (H1N1) (PR8) was grown in fertilized chicken eggs. Eggs were infected at day 9 , incubated at $37^{\circ} \mathrm{C}$ for 2 days and virus harvested in the allantoic fluid at day 11. Allantoic fluid was harvested from uninfected chicken eggs for use as a negative control. Virus stocks were titred by plaque assay using MDCK cells grown to $90 \%$ confluence in 96-well dishes. Cells were washed with PBS and infected with serial dilutions of the virus in DMEM for $1 \mathrm{~h}$ at $37^{\circ} \mathrm{C}$. The inoculum was removed and cells were incubated with $200 \mu \mathrm{l}$ DMEM (medium containing $1.4 \% \mathrm{BSA}, 2 \mu \mathrm{g} / \mathrm{ml}$ of trypsin and 1x penicillin/streptomycin antibiotics (VX15140122, Fisher)) at $37^{\circ} \mathrm{C}, 5 \% \mathrm{CO}_{2}$ for 2-3 days. Virus plaques were visualized by staining with 1:200 mouse H36-4.5-2 anti-HA antibodies (in-house monoclonal provided by A. Easton) and an Alexa-594 labelled secondary anti-mouse antibody diluted 1:250 (A-11062, Invitrogen, UK).

\section{Collection of aerosols containing influenza virus and quantification of viable influenza virus}

Influenza aerosols were generated from a $1 \mathrm{ml}$ suspension containing $10^{10}$ plaque-forming units (PFU)/ml using a PariTherm nebuliser (PARI Respiratory Equipment Inc, Midlothian, VA, USA). This was connected to a viable impactor (6-stage Microbial sampler, Westech Scientific Instruments, Upper Stondon, Bedfordshire, UK) to collect and fractionate the aerosolised influenza virus particles by aerodynamic size (Figure 2A) as described previously ${ }^{16}$. Particles were impacted into separate Petri dishes containing $20 \mathrm{ml}$ of medium (RPMI Media 1640, Life Technologies, Grand Island, NY, USA) with added penicillin $(50 \mu \mathrm{g} / \mathrm{ml})$, streptomycin $(50 \mu \mathrm{g} / \mathrm{ml})$ and Fungizone $(1 \mu \mathrm{g} / \mathrm{ml})$.

Quantification of viable influenza virus in the fractionated aerosolized particles was performed using MDCK cells seeded into 96 well plates. Triplicate wells were exposed to $200 \mu \mathrm{l}$ of a $\log$ dilution series of the impacted air sample at $37^{\circ} \mathrm{C}$ in $5 \% \mathrm{CO}_{2}$ for 2 hours. The sample was removed using two washes with DMEM and incubated at $37^{\circ} \mathrm{C}$ for 48 hours. Influenza virus was detected as above by direct immune-fluorescent staining. The number of immune-fluorescent plaques per well were counted and the total PFU in each sample calculated.

\section{Delivery of virus to primary epithelial cell cultures}

This was performed using the traditional method of liquid immersion cells with fluid containing virus or using our bespoke aerosolisation system (Figure 1). Frozen aliquots of influenza virus were thawed immediately prior to use and diluted in BEBM basal medium (Lonza, CC3171) to $1 \times 10^{5} \mathrm{PFU} / \mathrm{ml}$. Prior to infection, the basolateral culture medium was removed and the apical surfaces of ALI cultures were rinsed with medium. Next, $200 \mu \mathrm{l}$ of viral suspension (multiplicity of infection (MOI) of $\sim 0.1$ (based on an estimate of $5 \times 10^{5}$ cells/ALI well)) in BEBM was directly applied to the apical surface for 1 hour and then removed. We also delivered the virus using a bespoke nebulisation system (Figure 1A), which allows aerosols to be delivered to the surface of ciliated cells in culture under direct vision using an inverted microscope (Figure 1B). We generated influenza aerosols from suspensions containing doses of $10^{5}$, $10^{6}$ or $10^{7} \mathrm{PFU} / \mathrm{ml}$ using the Pari-Therm nebuliser. The nebulised virus was then delivered directly to the Transwell inserts via a static-free stainless-steel pipe to negate the effect of static charge on the aerosolised particles generated. Delivery to the cells in culture was via a stainless-steel t-piece at the end of the steel pipe. Both ends were clear to both reduce any pressure effects on the ciliated cultures and to allow real-time observation by high-speed video photography. The entire system was encased in a heated $\left(37^{\circ} \mathrm{C}\right)$ Perspex chamber, to mimic body temperature and to prevent the spread of the biological agents. The Pari-Therm was chosen as it warms the aerosols to approximately $32^{\circ} \mathrm{C}$ thus reducing the possible negative cellular effects of cold aerosol landing on the cells. Cultures were exposed to influenza aerosols for 1 minute. The nebuliser was then switched off and the cultures left for 1 hour. All cultures were maintained at $37^{\circ} \mathrm{C}$. 


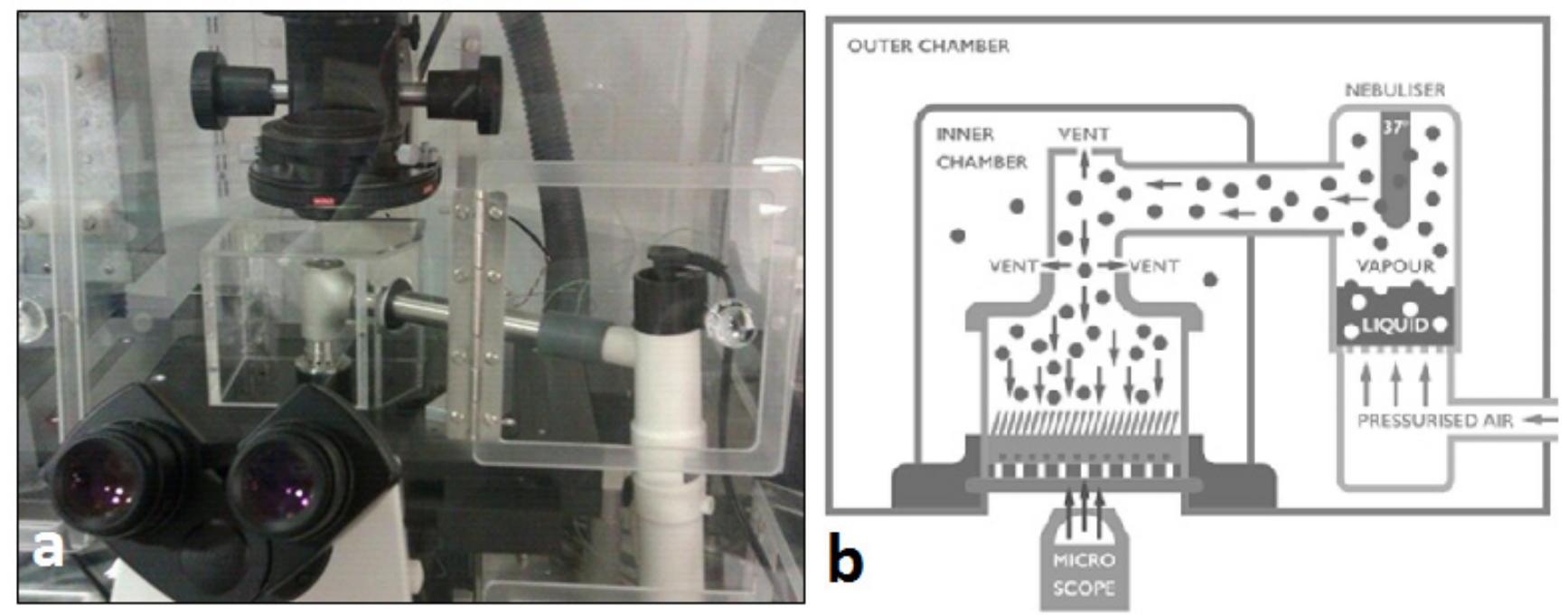

Figure 1. (A) Photograph and (B) diagram of the cell culture aerosolisation system. Aerosol generated in the Pari-Therm by compressed gas is heated by an internal heater to $32^{\circ} \mathrm{C}$ and transported via aluminium tubing, to reduce static attraction of particles, to cell cultures grown at an air-liquid interface. Vents at the top and base of the 't-piece' were incorporated to reduce the pressure effect of the compressed gas used to power the nebuliser on the cells in culture. The open top vent allowed continual observation, with high-speed video imaging, during nebulisation. The cells were contained in an inner chamber heated to $37^{\circ} \mathrm{C}$ to prevent leakage of biological aerosols in to the atmosphere. The nebuliser and inner chamber were surrounded by an outer Perspex chamber, heated to $37^{\circ} \mathrm{C}$ to help stabilise experimental temperature and to prevent cooling of the aerosolised aerosol as it passed from the nebuliser to the cells in culture.

Control wells received nebulised allantoic fluid without virus in BEBM. Cells were then washed three times with BEBM to remove unbound virus and the infections were allowed to continue for up to 24 hours. At this time the apical surface of the cells was rinsed and the wash was stored at $-80^{\circ} \mathrm{C}$ for plaque assay and cytokine analyses. Cells were fixed overnight at $4{ }^{\circ} \mathrm{C}$ with $4 \%$ paraformaldehyde in phosphate buffered saline (PBS) for immunostaining.

\section{Ciliary beat frequency and beat pattern}

Cultures were placed in an incubation chamber at $37^{\circ} \mathrm{C}$ for 30 minutes and were observed via an inverted microscope system (Nikon TU1000, UK). Beating cilia were recorded using a digital high-speed video camera (Lake Image Systems, USA) at a rate of 250 frames per second using an $\mathrm{x} 40$ objective as previously described ${ }^{17}$. Ciliary dyskinesia was defined as ciliated cells that displayed uncoordinated motile cilia or those that beat with a stiff, flickering or twitching motion. The dyskinesia index was calculated as the percentage of dyskinetic ciliated cells relative to the total number of motile ciliated cells.

\section{Chemokine and cytokine and nitric oxide analysis}

Chemokines and cytokines were measured using a 96-well multispot assay (Meso Scale Discovery, Maryland, USA) as described previously ${ }^{10}$. The lower limit of detection was $1 \mathrm{pg} / \mathrm{ml}$.

\section{Indirect immunofluorescence microscopy}

Cells were fixed with $4 \%$ (w/v) paraformaldehyde in phosphatebuffered saline (PBS) overnight at $4{ }^{\circ} \mathrm{C}$. Following fixation, cells were washed three times with PBS, blocked with $3 \%(w / v)$ BSA in PBS for 10 minutes, and washed again three times with
PBS. All subsequent antibody incubations were carried out in PBS containing $1 \%(\mathrm{w} / \mathrm{v})$ BSA. Reagents used for immunofluorescence in this study were anti-influenza virus HA mouse monoclonal antibody H36-4.5-2 (40 $\mu \mathrm{g} / \mathrm{ml})$ as above and $1: 50$ anti- $\beta$-tubulin III rabbit monoclonal antibody (ab52623, Abcam). Subsequent incubations were performed as described previously ${ }^{10}$. High resolution optical sections were obtained using a Leica TCS SP5 confocal microscope using a $63 \mathrm{x}$ oil objective (numerical aperture, 1.4). Images acquired by confocal microscopy were rendered by Imaris Software v7.2 (Bitplane AG).

Images obtained using a 20x objective were used to quantify the level of anti- $\beta$-tubulin III staining by mean fluorescence intensity using NIS Elements Software (Nikon Instruments, Kingston, UK).

\section{Statistical analysis}

Statistical analysis was performed using GraphPad Prism 5 (GraphPad, San Diego, CA, USA). Any difference in the ciliary activity observed for control and influenza virus was determined using paired t-tests. Within-group comparisons of the magnitude of chemokine/cytokine release were conducted using a Wilcoxon signed ranks test. Between-groups comparisons were performed using the Mann-Whitney U-test.

\section{Ethics Statement}

Ethical approval was obtained from the University of Leicester Committee for Research Ethics (Leicester, UK). All adult subjects provided informed written consent.

Work with embryonated hen's eggs was approved by the University of Warwick Animal Welfare and Ethical Review Body 

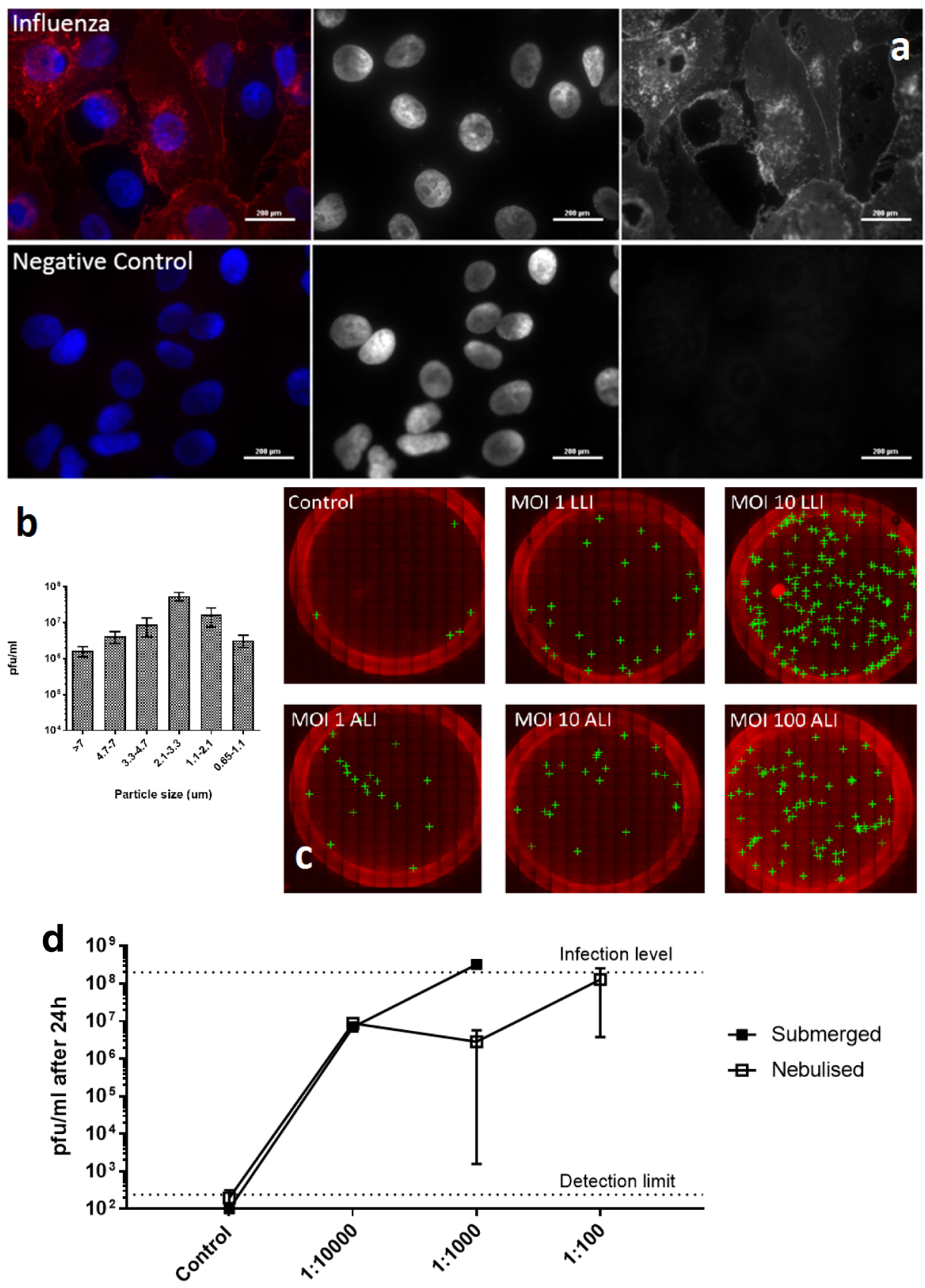

Dilution Factor of inoculum

Figure 2. Infection of cells with aerosolised virus. (A) A549 cells infected with aerosolised influenza virus. Cells were stained with an antibody specific for influenza virus HA antigens (red). Nuclei were stained using Hoescht (blue). No influenza virus was found after 24 hours in the control wells. (B) Quantification of the amount (PFU/ml) of viable influenza particles collected by the different stages of the six-stage viable impactor (Westech) used in this study. The impactor consists of six stages allowing fractionation of the particles into the following aerodynamic size ranges: $7 \mu \mathrm{m}$ and above (Stage 1); 4.7-7 $\mu \mathrm{m}$ (Stage 2); 3.3-4.7 $\mu \mathrm{m}$ (Stage 3); 2.1-3.3 $\mu \mathrm{m}$ (Stage 4); 1.1-2.1 $\mu \mathrm{m}$ (Stage 5); 0.65-1.1 $\mu \mathrm{m}$ (Stage 6). The nebuliser was loaded with a dose of $2 \mathrm{ml}$ of $2 \times 10^{4} \mathrm{HAU} / \mathrm{ml} \sim 10^{10}$ influenza A/PR/8 virus particles and run for 10 minutes. Viable virus was quantified by plaque assay using MDCK cells. All data the mean average of $n=3$ impactor runs. (C) Efficiency of liquid immersion system (LIS) verses aerosol (ALI) flu delivery on to Transwell inserts containing MDCK cultures grown at an air-liquid interface. Cells were stained with an antibody specific for influenza virus HA antigens (red) and the whole well was imaged for infected cells, a reduction in fluorescence indicates a reduction in the number of infected cells. These images indicate a 10-fold loss in viral progeny when virus was aerosolised compared to liquid immersion infections $(n=3)$. Arrows indicate infected cells. (D) The viral titre (PFU/ml) of apical supernatants collected from MDCK cells infected with aerosolised or liquid immersion preparations of influenza A/PR/8 virus for 24 hours ( $n=3$ ). Clear squares represent the aerosol method, filled squares represent the liquid immersion method. Values represent the mean ( \pm SD). 
carried out under a licence approved by the UK Home Office as required by the Animal Scientific Procedures Act (1986).

\section{Results}

\section{Characterisation of influenza aerosols}

The Pari-therm nebuliser generated infectious influenza virus aerosol particles that ranged from 0.65 to $>7 \mu \mathrm{m}$ in size (Figure 2B). A substantial proportion (84\%) of infectious influenza virus was contained in particles less than $4.7 \mu \mathrm{m}$, a particle size where inhalation into the lower respiratory tract is likely. The total number of infectious influenza virus particles produced by the nebuliser was $2 \times 10^{9} \mathrm{PFU}$ indicating an approximate 5-fold loss in viral viability or infectivity from the inoculum $\left(10^{10} \mathrm{PFU}\right)$. Raw PFU data are available on Figshare ${ }^{18}$

Development and validation of the aerosol delivery system We found that nebulising $1 \times 10^{8}$ PFU for 1 minute resulted in $10^{5} \mathrm{PFU}$ landing on the membrane growth area of an empty Transwell (no cells). This aerosol inoculum (MOI of approximately 0.2 ) was shown to result in approximately $20 \%$ of infected epithelial cells being virus-positive after $24 \mathrm{~h}$. In separate wells, cells were infected via liquid immersion using a viral inoculum of MOI of 0.2. This was to confirm that any effects were due to the amount of virus landing on the cells, rather than any difference in the ability of the virus to infect (Figure 2C). This data showed that the nebuliser was required to contain a virus preparation that was ten-fold higher than that delivered in the immersion system. This was reflected in the amount of virus released by these infected cells into the apical fluid after $24 \mathrm{~h}$ infection (Figure 2D).

Effect of influenza virus infection on ciliary function. We found that influenza virus infection significantly reduced the proportion of epithelial cells with motile cilia (Table 1). Using the standard liquid immersion method, the number (median $(\mathrm{IQR}))$ of ciliated epithelial cells per field significantly reduced $(\mathrm{P}<0.05)$ as early as 18 hours post-influenza virus infection (20 (11-39) cells/4.2 $\mathrm{mm}^{2}$ ) compared to the uninfected controls
(27 (27-37) cells/4.2 $\mathrm{mm}^{2}$ ). After 24 hours infection this reduced to less than half $\left(16(11-29)\right.$ cells $\left./ 4.2 \mathrm{~mm}^{2}\right)$ that detected in the uninfected controls $\left(33(27-40)\right.$ cells/4.2 $\left.\mathrm{mm}^{2}\right)$. Despite this reduction in the numbers of cells with motile cilia, the ciliary beat frequency of the motile cilia on other ciliated cells in culture was unaffected by influenza virus infection over the 24-hour study period. The median (IQR) ciliary beat frequency of motile cilia on influenza virus infected nasal ciliated cells was indistinguishable after 24 hours $(14.7(9.7-15.2) \mathrm{Hz})$ from the uninfected controls (14.0 (11.7-15.7) $\mathrm{Hz}) \quad(\mathrm{P}=0.87)$. The cilia that remained motile following influenza virus infection showed no evidence of ciliary dyskinesia. The median (IQR) dyskinesia index was the same after 24 hours $(0 \%(0 \%-5 \%))$ as the uninfected controls $(0 \%(0 \%-0 \%))(\mathrm{P}=0.87)$. Raw data on ciliary activity are available on Figshare ${ }^{19}$.

Infection of ciliated epithelial cells by aerosolised influenza virus results in similar cytopathology as standard method. Human ciliated airway epithelial cells infected with aerosolised influenza A virus resulted in similar levels of cytopathology (cells rounding, lifting off and tight junctions detected) as those immersed in the same concentration of influenza virus. The number (median (IQR)) of motile ciliated epithelial cells per field reduced two-fold to $7.8(4.0-10.4)$ cells $\left./ 4.2 \mathrm{~mm}^{2}\right)$ compared to the pre-infection level $\left(14.0(5.2-22.8)\right.$ cells $\left./ 4.2 \mathrm{~mm}^{2}\right)$. The ciliary beat frequency $(\mathrm{CBF})$ of the remaining motile ciliated epithelial cells exposed to aerosolised inoculum of influenza A virus (16.6 (15.4-17.6) Hz) remained unchanged from pre-infection level $(15.8(15.2-16.3) \mathrm{Hz})$ and the uninfected control of 15.5 (13.1-17.3) Hz. These values do not account for cilia on cells that have become static.

The concentration of inflammatory mediators detected in the apical fluid of cell cultures subjected to the aerosol delivery of the control and influenza virus preparations resulted in significantly lower levels of inflammatory mediators after 24 hours compared to the liquid immersion system (Table 2). In addition to lower concentrations, the two systems produced a different cytokine

Table 1. Ciliary beat frequency, motility index, and dyskinesia index of healthy nasal respiratory epithelial cells in pseudostratified air-liquid interface (ALI) cultures infected with influenza A/PR/8 virus using the aerosol or liquid immersion delivery system. Data expressed as median (IQR).

\begin{tabular}{|c|c|c|c|c|c|c|c|}
\hline \multirow{2}{*}{$\begin{array}{l}\text { Delivery } \\
\text { method }\end{array}$} & \multirow{2}{*}{$\begin{array}{l}\text { Time } \\
\text { p.i. (h) }\end{array}$} & \multicolumn{2}{|c|}{ Ciliary beat frequency $(\mathrm{Hz})$} & \multicolumn{2}{|c|}{ Motility index ${ }^{*}$} & \multicolumn{2}{|c|}{ Dyskinesia index $(\%) \dagger$} \\
\hline & & Control & Virus & Control & Virus & Control & Virus \\
\hline \multirow{4}{*}{ 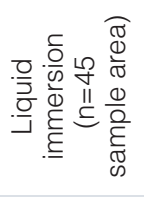 } & 0 & $15.0(11.6-18.7)$ & $14.5(12.7-18.1)$ & $26.7(24.4-45.9)$ & $28.9(17.8-49.5)$ & $0.0(0.0-1.4)$ & $0.0(0.0-7.4)$ \\
\hline & 4 & 5.1) & $12.5(1$ & 26.7 & 24.4( & $0.0(C$ & $-5.6)$ \\
\hline & 18 & $14.0(13.1-14.0)$ & $12.3(10.8-13.4)$ & $26.7(26.7-36.7)$ & $20.0(11.1-38.5) \neq$ & $0.0(0.0-0.0)$ & $2.1(0.0-4.8)$ \\
\hline & 24 & $14.0(11.7-15.7)$ & $14.7(9.7-15.2)$ & $33.3(26.7-40.0)$ & $15.6(11.1-28.9) \neq$ & $0.0(0.0-0.0)$ & $0.0(0.0-5.0)$ \\
\hline \multirow{2}{*}{ 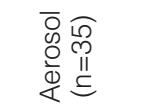 } & 0 & $15.0(10.2-16.9)$ & $15.8(15.2-16.3)$ & $10.6(6.8-18.4)$ & 14.0 & nd & nd \\
\hline & 24 & $15.5(13.1-17.3)$ & $16.6(15.4-17.6)$ & $6.9(2.2-10.5) \neq$ & $7.8(4.0-10.4) \neq$ & $3.5(2.8-4.5)$ & $3.5(0.8-4.8)$ \\
\hline
\end{tabular}

${ }^{*}$ Motility index, number of motile ciliated cells per sample area of $\sim 4200 \mu \mathrm{m}^{2}$ ( $\mathrm{n}=2-9$ donors). +Dyskinesia index, percentage of dyskinetically beating cilia amongst all cilia examined $n=3$ donors. $¥$ Significant difference from time point $0(P<0.05)$ using a Wilcoxon signed ranks test. nd, not done; p.i., post-infection. 
Table 2. The median (IQR) cytokine response from human nasal ciliated epithelial cell cultures infected with aerosolised or liquid immersion influenza $A$ virus for 24 hours ( $n=3-7$ donors).

\begin{tabular}{|c|c|c|c|c|c|c|c|}
\hline \multirow{2}{*}{\multicolumn{2}{|c|}{$\begin{array}{l}\text { Chemokine/cytokine } \\
\text { (pg/ml) }\end{array}$}} & \multicolumn{2}{|c|}{ Liquid immersion $(n=7)$} & \multirow{3}{*}{$\begin{array}{c}\begin{array}{c}\text { Fold } \\
\text { Change }\end{array} \\
0.7\end{array}$} & \multicolumn{2}{|c|}{ Aerosol delivery $(n=3)$} & \multirow{3}{*}{$\begin{array}{c}\text { Fold } \\
\text { Change } \\
1.0\end{array}$} \\
\hline & & \multirow{2}{*}{$\begin{array}{c}\text { Control } \\
100(76-143)\end{array}$} & \multirow{2}{*}{$\begin{array}{c}\text { Influenza } \\
66(40-122)\end{array}$} & & Control & Influenza & \\
\hline \multirow{5}{*}{$\bar{E}$} & IFN- $\gamma$ & & & & $10(9-11)$ & $10(9-11)$ & \\
\hline & IL-1及 & $49(34-57)$ & $36(26-44)$ & 0.7 & $12(11-14)$ & $13(11-14)$ & 1.1 \\
\hline & IL-2 & $18(17-27)$ & $19(12-21)$ & 1.1 & $3(2-4)$ & $3(3-4)$ & 1.0 \\
\hline & IL-12p70 & $21(12-25)$ & $16(8-32)$ & 0.8 & $4(4-4)$ & $4(3-5)$ & 1.0 \\
\hline & TNF $\alpha$ & 133 (105-147) & $110(61-152)$ & 0.8 & $12(11-14)$ & $11(9-16)$ & 0.9 \\
\hline \multirow{5}{*}{$\stackrel{\text { N }}{\mathfrak{F}}$} & IL-4 & $9(7-13)$ & $6(5-12)$ & 0.7 & $3(2-3)$ & $3(2-3)$ & 1.0 \\
\hline & IL-5 & $36(30-42)$ & $38(22-43)$ & 1.1 & $0(0-0)$ & $0(0-0)$ & 1.0 \\
\hline & IL-6 & $548(418-1525)$ & $333(107-1304)^{*}$ & 0.6 & 968 (700-1235) & $1297(1107-1371)$ & 1.3 \\
\hline & IL-10 & $71(37-80)$ & $26(20-77)$ & 0.4 & $2(2-3)$ & $3(2-4)$ & 1.5 \\
\hline & IL-13 & $70(65-76)$ & $55(22-76)$ & 0.8 & $50(48-53)$ & $65(55-65)^{*}$ & 1.3 \\
\hline CCL11 & Eotaxin & 409 (307-477) & 435 (408-457) & 1.1 & $17(14-20)$ & $20(19-21)$ & 1.2 \\
\hline CCL4 & MIP-1及 & $33(17-54)$ & $37(33-52)$ & 1.1 & nd & nd & 1.0 \\
\hline CCL26 & Eotaxin-3 & $6593(3932-11580)$ & $5516(4564-8620)$ & 0.8 & nd & nd & 1.0 \\
\hline CCL17 & TARC & $295(227-415)$ & 339 (302-368) & 1.1 & nd & nd & 1.0 \\
\hline CCL2 & MCP-1 & 8299 (4949-15839) & $7135(5515-14,185)$ & 0.9 & 309 (254-364) & $631(539-686)^{\star}$ & 2.0 \\
\hline CCL22 & MDC & $\begin{array}{c}20545 \\
(9986-23,181)\end{array}$ & $\begin{array}{c}22,812 \\
(20,342-30,853)^{\star}\end{array}$ & 1.1 & nd & nd & 1.0 \\
\hline CCL13 & MCP-4 & $94(42-134)$ & $274(95-337)$ & 2.9 & $13(12-14)$ & $18(16-20)^{\star}$ & 1.4 \\
\hline CXCL8 & IL-8 & 594 (506-989) & $887(692-1190)^{\star}$ & 1.5 & $\begin{array}{c}65,523 \\
(44,759-86,287)\end{array}$ & $\begin{array}{c}109,039 \\
(86,701-113,242)\end{array}$ & 1.7 \\
\hline CXCL10 & IP-10 & $698(433-974)$ & $4140(823-19,884)$ & 5.9 & $112(105-120)$ & $781(718-1236)^{\star}$ & 7.0 \\
\hline
\end{tabular}

*Significant difference from control at same time point $(\mathrm{P}<0.05)$ using a Wilcoxon signed ranks test. nd, not detected

response to influenza virus infection. Among the ten cytokines measured, influenza virus infection by liquid immersion caused a significant $(\mathrm{P}<0.05)$ downregulation of IL-6 secretion to a median (IQR) of $333 \mathrm{pg} / \mathrm{ml}$ (107-1304) from $548 \mathrm{pg} / \mathrm{ml}$ (4181525 ) in control uninfected cells. However, the aerosol delivery of influenza virus resulted in an upregulation of IL-6 to $1297 \mathrm{pg} / \mathrm{ml}$ (1107-1371) from $968 \mathrm{pg} / \mathrm{ml}$ (700-1235) in control uninfected cells. The same trend was seen with another antiinflammatory cytokine IL-13, which showed significant upregulation in the aerosol group from the control $50 \mathrm{pg} / \mathrm{ml}(48-53)$ to $65 \mathrm{pg} / \mathrm{ml}$ (55-65) following infection, compared to a downregulation in the liquid immersion group from $70 \mathrm{pg} / \mathrm{ml}$ (65-76) to $55 \mathrm{pg} / \mathrm{ml}$ (22-76), respectively.

Among the nine chemokines measured, ciliated epithelial cells exposed to a liquid immersion inoculum of influenza virus resulted in a significant upregulation of CCL22 from a median (IQR) uninfected control of $2,0545 \mathrm{pg} / \mathrm{ml}$ (9986-23181) to $22812 \mathrm{pg} / \mathrm{ml}(20,342-30,853)$ (Table 2), whereas exposure to a aerosolised inoculum and control solution resulted in undetectable levels of this chemokine. MCP-1 and MCP-4 both showed a significant $(\mathrm{P}<0.05)$ increase following aerosolised delivery, but this was not significantly altered in the group exposed to the liquid immersion inoculum. However, both delivery systems show similar CXCL8 and CXCL10 responses to influenza virus, where production increased approximately 1.5 -fold and 6.5-fold, respectively. In the liquid immersion delivery system, median (IQR) CXCL8 increased from $594 \mathrm{pg} / \mathrm{ml} \mathrm{(506-989)}$ in the uninfected control cells to $887 \mathrm{pg} / \mathrm{ml}$ (692-1190). The aerosol delivery system resulted in much higher concentrations of CXCL8 from $65,523 \mathrm{pg} / \mathrm{ml}(44,759-86,287)$ in the uninfected control cells to $109,039 \mathrm{pg} / \mathrm{ml}(86,701-113,242)$ compared to the liquid immersion system. CXCL10 increased from $698 \mathrm{pg} / \mathrm{ml}$ (433-974) in the uninfected control cells to $4140 \mathrm{pg} / \mathrm{ml}$ (823-19884). MIP-1 $\beta$, Eotaxin-3, TARC and MDC were unable to be detected in the apical fluids of cells exposed to aerosolised medium or virus, but liquid immersion the membrane with medium alone caused levels to exceed $30 \mathrm{pg} / \mathrm{ml}, 3500 \mathrm{pg} / \mathrm{ml}$, $290 \mathrm{pg} / \mathrm{ml}$ and 20,000 pg/ml, respectively. Raw data from measurement of inflammatory mediators are available on Figshare $^{20}$.

The distribution of influenza HA antigen on human ciliated epithelial cells. We have previously shown that RSV preferentially infects ciliated cells and this infection progresses with viral antigen being displayed on the cell surface, leading to viral antigen moving into the ciliary shaft after $24 \mathrm{~h}^{1,2}$. To determine whether influenza virus follows a similar pattern of viral antigen 
spread we used immunofluorescent staining to detect influenza virus haemagglutinin (HA) and ciliary ( $\beta$-tubulin III) antigens on infected cells. We found a high level of influenza virus HA antigen accumulated on the distal ends of the cilia (ciliary tips) (Figure 3A, panel A) and the apical cell surface of ciliated cells (Figure 3A, panel B). We observed the co-localisation of influenza virus and anti- $\beta$-tubulin III, indicating virus HA antigen is displayed on the ciliary axoneme (Figure 3A, panel C). Notably, we found that cells either displayed viral antigens only on the ciliary tips or the full length of the ciliary axoneme. In cells where the apical membrane (cell surface) showed evidence of viral antigen, antigen was always present over the full length of the ciliary axoneme suggesting spread of antigen from the tip to the base of the cilium. Raw mean fluorescence intensity values are available on Figshare

A number of cells were seen with partial and in some cases almost complete loss of cilia (Figure 3A, panel D). In these cells fragments of $\beta$-tubulin III staining was seen the surface of the cell indicating that the cilia may have been lost from infected ciliated cells. To determine whether cilia were lost as a result of influenza infection, we compared the level of anti- $\beta$-tubulin III, a marker of cilia, (as measured by fluorescence intensity) in control and infected cultures. This showed that influenza infection resulted in significantly $(\mathrm{P}<0.01)$ less anti- $\beta$-tubulin III staining compared to uninfected cultures (Figure 3C).

\section{Discussion}

To our knowledge, this study shows for the first time that human ciliated epithelial cells from the upper airway are a target of influenza virus infection and suggests infection is primarily seen in ciliated cells. Previous studies have indicated ciliated cell tropism by influenza virus in the lower airway of humans and ferrets $^{4-6}$. Our study demonstrated that not only are nasal ciliated cells also a target, but early influenza virus infection causes a significant decrease in the number of cells with motile cilia. At 24 hours after influenza infection the number of motile cilia present in the epithelial cultures reduced to under half that seen in uninfected control cells. Such loss could be due to cilia being cleaved from the cell surface, cells being destroyed or
A
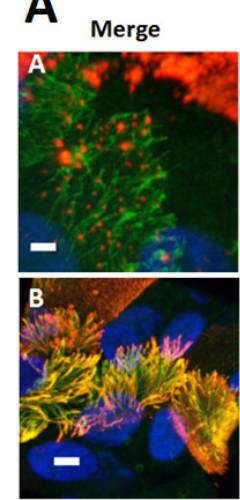

C
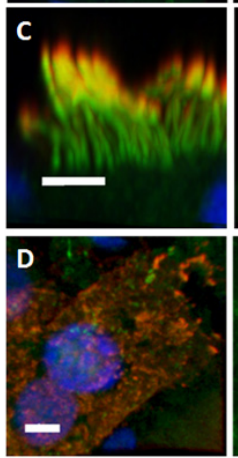

$\beta$-tubulin III
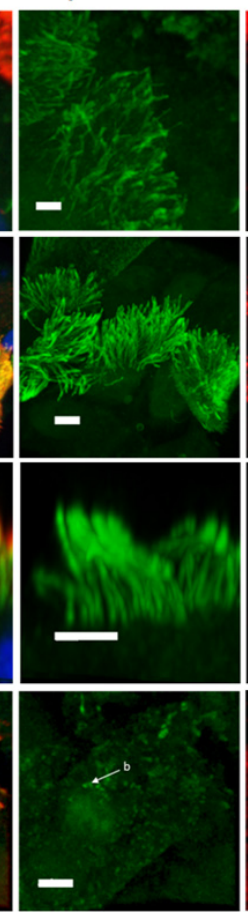

Influenza HA
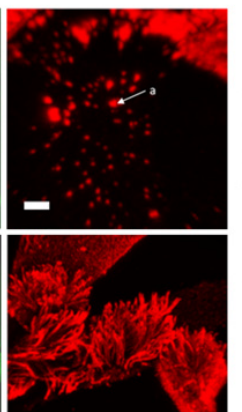

B
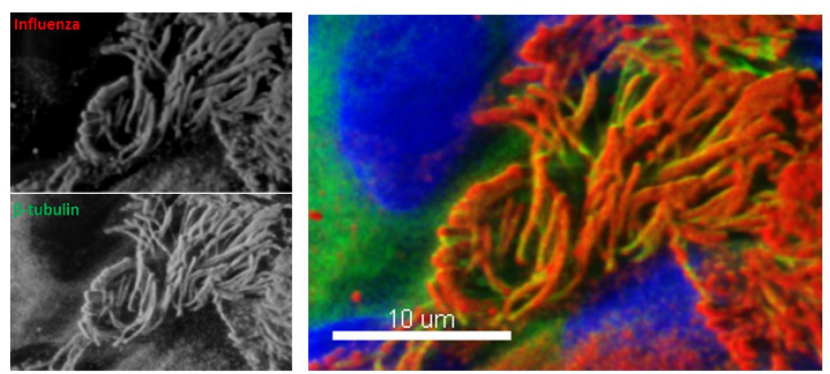

\section{C}

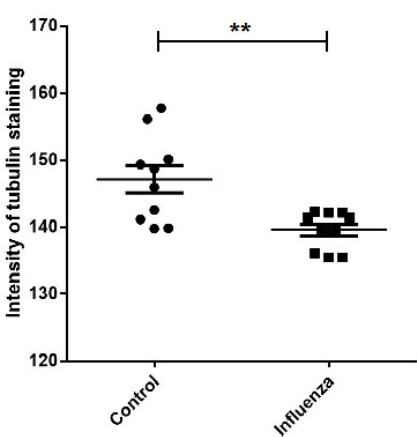

Figure 3. (A) Immunolocalisation of influenza virus HA protein and cilia proteins on the surface of infected ciliated epithelial cells grown at airliquid interface. Panel A: ciliated cell displaying viral antigen on the ciliary tips but not on the shaft of the cilia and not on the apical cell surface (virus indicated by the arrow a). Panel B: influenza virus infected ciliated epithelial cells $24 \mathrm{~h}$ post-infection showing viral antigen displayed on the surface of the cell (red) and the ciliary axoneme (yellow in merge). Panel C: Z-projection ofinfluenza virus infected ciliated epithelial cells $24 \mathrm{~h}$ post infection showing viral antigen displayed on the ciliary shaft (yellow in merge).Panel $\mathbf{D}$ : denuded ciliated cells displaying viral antigen on the surface of the cell and fragments of ciliary $\beta$-tubulin III staining (indicated by arrow b). Cells were co-stained with antibodies against $\beta$-tubulin III to detect the axonemal microtubules (FITC) and an antibody specific for influenza virus HA antigens (Alexa-594). Nuclei were stained using Hoescht (blue in merge). Merged images are shown where green indicates $\beta$-tubulin III protein, red indicates influenza $\mathrm{HA}$ and yellow indicates areas of influenza-tubulin antigen co-localisation. All images show the maximum intensity projection. Scale bars, $5 \mu \mathrm{m}$. (C) Quantification of tubulin staining on the surface of control (uninfected) and influenza virus infected ciliated epithelial cell cultures grown at air-liquid interface. Values represent the mean (and SD) fluorescence intensity of tubulin staining from 10 images (approx. 200 cells per image). ${ }^{*} \mathrm{P}<0.01$ vs control. 
cells undergoing apoptosis ${ }^{21}$ or the ciliated cells being shed from the surface. Confocal images suggested loss of cilia from the apical surface of ciliated cells was at least in part responsible for the reduction in cilia. Infected cells with no detectable cilia had evidence of small amounts of anti- $\beta$-tubulin III staining at their surface, suggesting cilia had been cleaved, supporting the indication of tropism of influenza for ciliated cells $\mathrm{s}^{4-6}$. To further confirm the loss of ciliary axonemes following influenza infection we compared the levels of anti- $\beta$-tubulin III staining in infected and control wells. The levels were significantly reduced in infected wells, again supporting our finding that the number of cilia had decreased. These results are consistent with findings of reduced mucociliary transport in tracheal cultures and the tracheas in animals infected with influenza virus ${ }^{12,22,23}$. It is possible that in vivo, this rapid reduction in the number of motile ciliated cells may reduce mucociliary clearance early in the infective process, predisposing the respiratory tract to colonisation and infection by bacteria.

Increased ciliary dyskinesia is a common finding during infection of ciliated cells with bacteria and viruses such as RSV, $6,10,24$. However, influenza virus infection did not increase ciliary dyskinesia or reduce the ciliary beat frequency of the cilia that remained motile. Longer time courses are needed to determine the degree of further ciliary loss and to determine if ciliary function is affected.

We also found that influenza virus interacts with the ciliary tips and ciliary axonemes. In a number of images in our study influenza appeared to be present on the tips of cilia without the underlying cell being infected indicating that the virus may initially bind to the ciliary tip. On other cells, the ciliary tips and the top part of the ciliated shaft showed presence of antigen, with no antigen present on the rest of the ciliary membrane or cells surface, suggesting that virus may use the cilium as an entry point to the cell. Previous reports suggest that influenza virus budding occurs at the tips of the microvilli rather than the cilia themselves $^{13}$. Some cells showed antigen on the ciliary membrane and on the cell surface. However, no cells showed antigen on the cell surface without antigen being present on the full length of the ciliary membrane. As discussed above, cells without cilia where antigen was present also showed staining with anti$\beta$-tubulin III, suggesting they had previously been covered by cilia. These findings suggest a novel infective route by which influenza binds to the ciliary tips and enter the cell at that point with infection spreading down into the cell resulting in ciliary loss. The initial attachment to the ciliary tips rather than the cell surface, is consistent with the work of Button and colleagues $^{25}$ who have shown that particles greater than $40 \mathrm{~nm}$ are unable to penetrate between cilia to reach the surface of the ciliated cells. Influenza virus particles are between 80 to $120 \mathrm{~nm}$ in diameter ${ }^{26}$ and would not be expected to easily penetrate this barrier. It will be important to investigate if other strains and subtypes of influenza virus show differences in their tropism for ciliated epithelial cells.

Influenza virus is thought to be spread by aerosols made when infected individuals cough, sneeze or $\operatorname{talk}^{27}$. However, all human and in vitro studies to date have delivered infectious virus to subjects in solution. We aimed to determine whether there were any differences in the response of ciliated airway epithelial cells to influenza virus delivered in suspension compared to the aerosolised form. We first validated the method so that the cells received the same dose whether delivered by aerosol or by liquid immersion. We found that the infectious nature of the virus was not altered by aerosolisation and, accounting for virus loss, we detected the same level of cytopathology and cell tropism as we reported using the liquid immersion method. However, we observed a significant difference in the type of inflammatory response. In the liquid immersion system, we found that influenza virus infection resulted in a significant downregulation of the anti-inflammatory cytokine IL-6 compared to the uninfected control cells. Notably, this was not accompanied by significant upregulation of pro-inflammatory mediators and no other cytokine tested showed any change in levels. Using the aerosol delivery method, we found that another anti-inflammatory cytokine IL-13 significantly increased. This was accompanied by an increase in IL-6, although this increase was not statistically significant, most likely due to a type two error associated with the low number of repeats. This data indicates that aerosol delivery of influenza virus may lead to an anti-inflammatory Th2 cytokine response

We also detected a huge difference between the aerosol and liquid immersion methods in regard to the baseline concentrations of all nine chemokines we tested, with some up to 20,000 times higher in one method than the other. In all but one chemokine tested (CXCL8), liquid immersion the epithelium with medium resulted in much higher concentration of chemokine production after 24 hours compared to the aerosol delivery method. MIP-1 $\beta$, Eotaxin-3, TARC and MDC were not detected in the apical fluids of cells exposed to aerosolised medium or virus, but was detected when cells were infected by liquid immersion the membrane. This could indicate that liquid immersion the membrane removes or dilutes key feedback mechanisms that exist to regulate expression of these chemokines (or the carrier fluid in greater amounts is more toxic or liquid immersion means they are no longer exposed to air).

Despite these differences in the baseline levels of chemokines, the response to infection in both models followed the same trend. Both increased secretion of the interferon gamma-induced protein 10 (CXCL10) and the neutrophil recruitment chemokine CXCL8 following influenza virus infection. This is consistent with our previous findings of viral infection in this model ${ }^{10}$ and suggests that the response of the infected epithelium is to recruit neutrophils to aid the host antiviral response. Although we did not detect a significant change in CXCL8 secretion using the aerosol system, our data analysis were limited by the number of biological repeats $(n=3)$ and the natural variation in response we have previously reported from different donors ${ }^{10}$.

In summary, we have presented evidence that the influenza virus is tropic to ciliated cells of the upper respiratory tract and interacts directly with the tips and ciliary axoneme of motile cilia. Subsequent infection of the cell results in loss of cilia. We also show that the route of infection (via large or small droplet size) can impact on the type of inflammatory response produced by the cells within the first 24 hours. Further investigations 
using our unique aerosol delivery system should begin to address the mechanisms behind this.

\section{Data availability}

Figshare: Ciliary activity (raw data for ciliary beat frequency/ motility). https://doi.org/10.6084/m9.figshare.7803806 ${ }^{19}$.

Figshare: Confocal dataset (raw confocal z-stack of infected epithelial cells). https://doi.org/10.6084/m9.figshare.780355728.

Figshare: MFI of $\mathrm{B}$ tubulin with influenza infection (mean fluorescence intensity values for $\beta$-tubulin). https://doi.org/10.6084/ m9.figshare. $7803548^{29}$.

Figshare: chemokine/cytokine/NO multispot assay (raw data for chemokine/cytokine/NO assay). https://doi.org/10.6084/ m9. figshare. $7803545^{20}$.
Figshare: Viable Impactor results (raw pfu/ml of nebulised influenza A virus). https://doi.org/10.6084/m9.figshare.7803539 ${ }^{18}$.

Data are available under the terms of the Creative Commons Attribution 4.0 International license (CC-BY 4.0).

\section{Grant information}

This work was supported by grants from Action Medical Research (SP4499 and SP4118). This research was supported by the NIHR Great Ormond Street Hospital Biomedical Research Centre. The views expressed are those of the authors and not necessarily those of the NHS, the NIHR or the Department of Health.

The funders had no role in study design, data collection and analysis, decision to publish, or preparation of the manuscript.
1. Thompson WW, Shay DK, Weintraub E, et al:: Influenza-associated hospitalizations in the United States. JAMA. 2004; 292(11): 1333-40.

PubMed Abstract | Publisher Full Text

2. Thompson WW, Shay DK, Weintraub E, et al.: Mortality associated with influenza and respiratory syncytial virus in the United States. JAMA. 2003; 289(2): 179-86. PubMed Abstract | Publisher Full Text

3. Zhirnov OP, Ikizler MR, Wright PF: Cleavage of influenza a virus hemagglutinin in human respiratory epithelium is cell associated and sensitive to exogenous antiproteases. J Virol. 2002; 76(17): 8682-9.

PubMed Abstract | Publisher Full Text | Free Full Text

4. Zeng $\mathrm{H}$, Goldsmith CS, Maines TR, et al:: Tropism and infectivity of influenza virus, including highly pathogenic avian $\mathrm{H} 5 \mathrm{~N} 1$ virus, in ferret tracheal differentiated primary epithelial cell cultures. J Virol. 2013; 87(5): 2597-607. PubMed Abstract | Publisher Full Text | Free Full Text

5. van Riel D, Munster VJ, de Wit E, et al.: Human and avian influenza viruses target different cells in the lower respiratory tract of humans and other mammals. Am J Pathol. 2007; 171(4): 1215-23.

PubMed Abstract | Publisher Full Text | Free Full Text

6. Thompson $\mathrm{Cl}$, Barclay WS, Zambon MC, et al.: Infection of human airway epithelium by human and avian strains of influenza a virus. $J$ Virol. 2006; 80(16): 8060-8.

PubMed Abstract | Publisher Full Text | Free Full Text

7. Hirst RA, Gosai B, Rutman A, et al.: Streptococcus pneumoniae damages the ciliated ependyma of the brain during meningitis. Infect Immun. 2003; 71(10): 6095-100.

PubMed Abstract | Publisher Full Text | Free Full Text

8. Smith CM, Fadaee-Shohada MJ, Sawhney R, et al.: Ciliated cultures from patients with primary ciliary dyskinesia do not produce nitric oxide or inducible nitric oxide synthase during early infection. Chest. 2013; 144(5): 1671-1676.

PubMed Abstract | Publisher Full Text

9. Chilvers MA, McKean M, Rutman A, et al.: The effects of coronavirus on human nasal ciliated respiratory epithelium. Eur Respir J. 2001; 18(6): 965-70. PubMed Abstract | Publisher Full Text

10. Smith $\mathrm{CM}$, Kulkarni $\mathrm{H}$, Radhakrishnan $\mathrm{P}$, et al.: Ciliary dyskinesia is an early feature of respiratory syncytial virus infection. Eur Respir J. 2013; 43(2): 485-96. PubMed Abstract | Publisher Full Text

11. Smith CM, Sandrini S, Datta S, et al.: Respiratory syncytial virus increases the virulence of Streptococcus pneumoniae by binding to penicillin binding protein 1a. A new paradigm in respiratory infection. Am J Respir Crit Care Med. 2014; 190(2): 196-207.

PubMed Abstract | Publisher Full Text | Free Full Text

12. Hoke CH Jr, Hopkins JA, Meiklejohn G, et al.: Comparison of several wild-type influenza-viruses in the ferret tracheal organ-culture system. Rev Infect Dis. 1979; 1(6): 946-54.

PubMed Abstract | Publisher Full Text

13. Kolesnikova L, Heck S, Matrosovich T, et al:: Influenza virus budding from the tips of cellular microvilli in differentiated human airway epithelial cells. $J$ Gen Virol. 2013; 94(Pt 5): 971-6.

PubMed Abstract | Publisher Full Text

14. Zhang L, Peeples ME, Boucher RC, et al.: Respiratory syncytial virus infection of human airway epithelial cells is polarized, specific to ciliated cells, and without obvious cytopathology. J Virol. 2002; 76(11): 5654-66. PubMed Abstract | Publisher Full Text | Free Full Text

15. Avadhanula V, Rodriguez CA, Devincenzo JP, et al.: Respiratory viruses augment the adhesion of bacterial pathogens to respiratory epithelium in a viral species- and cell type-dependent manner. J Virol. 2006; 80(4): 1629-36. PubMed Abstract | Publisher Full Text | Free Full Text

16. Kulkarni H, Smith CM, Lee Ddo H, et al.: Evidence of Respiratory Syncytial Virus Spread by Aerosol. Time to Revisit Infection Control Strategies? Am J Respir Crit Care Med. 2016; 194(3): 308-16.

PubMed Abstract | Publisher Full Text

17. Chilvers MA, O'Callaghan C: Analysis of ciliary beat pattern and beat frequency using digital high speed imaging: comparison with the photomultiplier and photodiode methods. Thorax. 2000; 55(4): 314-7. PubMed Abstract | Publisher Full Text | Free Full Text

18. Smith C: Viable Impactor results. figshare. Dataset. 2019 http://www.doi.org/10.6084/m9.figshare.7803539.v1

19. Smith C: Ciliary activity. figshare. Dataset. 2019. http://www.doi.org/10.6084/m9.figshare.7803806.v1

20. Smith C: chemokine/cytokine/NO multispot assay. figshare. Dataset. 2019 http://www.doi.org/10.6084/m9.figshare.7803545.v1

21. Morris SJ, Price GE, Barnett JM, et al:: Role of neuraminidase in influenza virusinduced apoptosis. J Gen Virol. 1999; 80(Pt 1): 137-46. PubMed Abstract | Publisher Full Text

22. Pittet LA, Hall-Stoodley L, Rutkowski MR, et al.: Influenza virus infection decreases tracheal mucociliary velocity and clearance of Streptococcus pneumoniae. Am J Respir Cell Mol Biol. 2010; 42(4): 450-60. PubMed Abstract | Publisher Full Text | Free Full Text

23. Park K, Bakaletz LO, Coticchia JM, et al.: Effect of influenza A virus on ciliary activity and dye transport function in the chinchilla eustachian tube. Ann Otol Rhinol Laryngol. 1993; 102(7): 551-8. PubMed Abstract | Publisher Full Text

24. Freestone PP, Hirst RA, Sandrini SM, et al.: Pseudomonas aeruginosacatecholamine inotrope interactions: a contributory factor in the development of ventilator-associated pneumonia? Chest. 2012; 142(5): 1200-10. PubMed Abstract | Publisher Full Text

25. Button B, Cai LH, Ehre C, et al:: A periciliary brush promotes the lung health by separating the mucus layer from airway epithelia. Science. 2012; 337(6097): 937-41.

PubMed Abstract | Publisher Full Text | Free Full Text

26. Couch RB: Orthomyxoviruses. In: Baron S, editor. Medical Microbiology. 4th edition ed. Galveston (TX): University of Texas Medical Branch at Galveston; 1996. PubMed Abstract

27. Tellier R: Aerosol transmission of influenza A virus: a review of new studies. $J$ R Soc Interface. 2009; 6 Suppl 6: S783-90. PubMed Abstract | Publisher Full Text | Free Full Text

28. Smith C: confocal dataset. figshare. Dataset. 2019 http://www.doi.org/10.6084/m9.figshare.7803557.v1

29. Smith C: MFI of B tubulin with influenza infection. figshare. Dataset. 2019 http://www.doi.org/10.6084/m9.figshare.7803548.v1 


\section{Open Peer Review}

\section{Current Peer Review Status: ? ?}

\section{Version 1}

Reviewer Report 10 June 2019

https://doi.org/10.5256/f1000research.20259.r49307

(C) 2019 Short K. This is an open access peer review report distributed under the terms of the Creative Commons Attribution License, which permits unrestricted use, distribution, and reproduction in any medium, provided the original work is properly cited.

\section{Kirsty R Short}

Australian Infectious Diseases Research Centre, The University of Queensland, St Lucia, QLD, Australia

The paper by Smith et al, looks at the interactions between influenza virus and ciliated epithelial cells. Specifically, they compare infection and cytokine production after PR8/34 is delivered by immersion or aerosol. Overall, the article is well written and data is presented clearly. The infection via aerosol developed herein is a highly useful method and could be employed by other researchers in a variety of different contexts, including trying to better understand influenza virus transmission. Overall, I just have two minor points:

The authors use PR8/34 in this study and describe it as a 'human influenza virus'. Whilst originally this was a human influenza virus strain, it has since been passaged over 100 times in mice and is more accurately described as 'mouse adapted influenza'. Can the authors explain the choice of virus? It would be fantastic to see some of these data repeated with a real human influenza virus strain. At a bare minimum, it should be acknowledged that PR8/34 is a suboptiminal virus strain to use for studies with human cells.

The authors state that "the total number of infectious influenza virus particles produced by the nebuliser was 2x109 PFU indicating an approximate 5-fold loss in viral viability" yet in the discussion they state that "the infectious nature of the virus was not altered by aerosolisation". Can the authors please clarify? I would hypothesise that the process of aerosolisation resulted in more non-infectious virus particle which, in turn, stimulated a differential pro-inflammatory response in the ciliated epithelial cells. Can the authors please comment?

Is the work clearly and accurately presented and does it cite the current literature? Yes

Is the study design appropriate and is the work technically sound? Yes

Are sufficient details of methods and analysis provided to allow replication by others? 
Yes

If applicable, is the statistical analysis and its interpretation appropriate? Yes

Are all the source data underlying the results available to ensure full reproducibility?

No source data required

Are the conclusions drawn adequately supported by the results?

Partly

Competing Interests: No competing interests were disclosed.

Reviewer Expertise: influenza virus

I confirm that I have read this submission and believe that I have an appropriate level of expertise to confirm that it is of an acceptable scientific standard, however I have significant reservations, as outlined above.

Reviewer Report 11 April 2019

https://doi.org/10.5256/f1000research.20259.r46273

(C) 2019 Saint G. This is an open access peer review report distributed under the terms of the Creative Commons Attribution License, which permits unrestricted use, distribution, and reproduction in any medium, provided the original work is properly cited.

\section{Gemma L Saint}

Department of Women's and Children's Health, Institute of Translational Medicine, University of Liverpool, Liverpool, UK

The manuscript by Smith et al. explores the earliest stage of influenza infection on epithelial cells, specifically ciliated airway epithelium cells. They use striking confocal microscopy and high-speed video microscopy to visualise influenza-cilia interaction. In addition, they present a novel method of inoculating airway cells with influenza, which aims to better replicate presumed in vivo virus transmission. The lower level of cytokine responses in the non-infected control samples, using the aerosol method compared to liquid immersion, hint that this method may reduce responses elicited from immersion rather than infection itself. I anticipate this novel inoculation method will be invaluable in further studies.

The report is well written, and all data are explained in sufficient detail and presented well. All source data is accounted for and accessible to the reader.

I have answered 'partly' to the question - are the conclusions drawn adequately supported by the results - due to one point that I think requires some clarification if possible. 
I note the motility index for the aerosol method (both control and aerosol) was considerably lower than those of the liquid method. Is this normal variation for the ALI cultures? In addition, I note that for the controls of the aerosol model the motility index significantly reduces from time point 0 to $24 \mathrm{hrs}$. This is not addressed in the manuscript and the results section only references the motility of the cells from the liquid method. If I have understood correctly, the aerosol method does not show a change in motility index compared to the control as both show a reduction? Also could the authors explain why the dyskinesia index was not done for time point 0 for the aerosol method?

There is just one minor point which is the following sentence, which I think just needs amending for clarity. "This could indicate that liquid immersion the membrane removes or dilutes key feedback mechanisms that exist to regulate expression of these chemokines (or the carrier fluid in greater amounts is more toxic or liquid immersion means they are no longer exposed to air)."

Is the work clearly and accurately presented and does it cite the current literature? Yes

Is the study design appropriate and is the work technically sound?

Yes

Are sufficient details of methods and analysis provided to allow replication by others? Yes

If applicable, is the statistical analysis and its interpretation appropriate? Yes

Are all the source data underlying the results available to ensure full reproducibility? Yes

Are the conclusions drawn adequately supported by the results? Partly

Competing Interests: No competing interests were disclosed.

Reviewer Expertise: Bronchiolitis, RSV, RhV, NTM infection in CF

I confirm that I have read this submission and believe that I have an appropriate level of expertise to confirm that it is of an acceptable scientific standard, however I have significant reservations, as outlined above. 
The benefits of publishing with F1000Research:

- Your article is published within days, with no editorial bias

- You can publish traditional articles, null/negative results, case reports, data notes and more

- The peer review process is transparent and collaborative

- Your article is indexed in PubMed after passing peer review

- Dedicated customer support at every stage

For pre-submission enquiries, contact research@f1000.com 